\title{
The Law Impact on Murder Trial From Balinese Customary Law Perspective (Case Study In Desa Pakraman Sukawati)
}

\author{
Anak Agung Mas Adi Trinaya Dewi* dan Ni Made Trisna Dewi \\ Universitas Dwijendra, Denpasar, Bali \\ agungmasadi@gmail.com
}

Published: 15/08/2020

\begin{abstract}
How to cite:
Dewi, A, A, M, A, T., Dewi, N, M, T. 2020. The Law Impact on Murder Trial From Balinese Customary Law Perspective (Case Study In Desa Pakraman Sukawati). Sociological Jurisprudence Journal. Volume 3 Issue 2. Page 98 - 106. https://doi.org/10.22225/scj.3.2.1794.98-106
\end{abstract}

\begin{abstract}
This study aims to analyze what legal sanction and what consequences for the heirs trying to commit the murder of the inheritors in the perspective of Balinese customary law. The research method used is empirical research that is the observational and field study research in the Desa Pakraman Sukawati. Data were collected through observation. The result of the research is that the legal sanction for the heirs in perspective of Balinese customary law is a sentence of sanction given by Balinese traditional court law. The criminal matters are resolved in traditional court and it is not yet exist in the criminal code or state law. This sanction for violation of mistreatment of the heir tried to murder the inheritors occurred in Desa Pakraman Sukawati is determined by village peace judge. This is specially done by Prajuru Adat (Balinese indigenous custom village officers). The legal consequences described on Balinese customary law are based on Article 838 of the Civil Code. It states that it is one of those who has been convicted or blamed for killing or attempting to kill the inheritors, the consequence is that the inheritance is void although the heirs are entitled for inheritance. It is a principle that every person including a person who has inheritance rights of inheritance does not receive anything. This has been determined by law and it is excluded from inheritance due to inappropriateness (onwaardig) to receive inheritance.
\end{abstract}

Keywords: Desa Pakraman, heir, inheritance, trying to commit the murder

\section{INTRODUCTION}

Inheritance customary law contains provisions governing the transfer of assets both tangible and intangible from inheritors to the heirs. The process of inheritance of assets may occur when the inheritor is still alive or after the death of the heir. Inheritance customary law according to (Nantri, 2007), is a process of inheriting both material and immaterial goods from inheritors to the heirs with an involvement of rights and obligations. This inheritance process is carried out by the inheritors. The inheritance is based on tangible and intangible assets, all of which involve rights and religious obligations. According to the Balinese customary law, this inheritance contains several elements, namely: (a) Traditional inheritance customary law is a rule, (b) the rule consists of the process of inheritance, (c) the obtained inheritance can be any tangible and intangible property, (d) the transfer of this inheritance takes place from generation to generation. The traditional Balinese inheritance law is the most difficult part of Balinese customary law. It is partly because of the differences on each region within the Balinese jurisdiction called desa (place), kala (time), and patra (condition). Regardless of either the number of inherited

items or customary court decisions, the study of inheritance Balinese customary law cannot be separated from family relationship. This is especially in link with the family kinship system. This is generally related to marriage pursued by the customary law community in Bali. Inheritance in Bali is largely determined by the applicable kinship system and the marriage process of the people.

The Balinese Hindu followers adhere to a patrilineal kinship system. The patrilineal kinship system 
in Bali is commonly referred to as the "kepurusa or purusa" (patrimonial) system. In this system, patrilineal kinship becomes the sole basis for this arrangement. The family of the father, or the male family lineage (kepurusa) is the most important ones for inheritance process. For example, the male family lineage inherits everything and the children are all following the patrilineal system. But, only boys later become descendants of the inheritance. In patrilineal system, male status is steadily concrete, while the status of girls is changed. This is because women follow their husbands and be part of their husband's family member when they got married. The inheritance Balinese customary law is determined that the heirs are sons (sentana rajeg) and legal adopted children. A daughter only has the right to enjoy the wealth of her parents as long as she is single. When girl gets married, the right of inheritance is null and void. The constitution and regulations clearly stipulate that every citizen is equal in law. Thus, there will be disharmony between the state law and inheritance Balinese customary law.

The theoretical study of the legal certainty can be interpreted as the legal instrument of a country that is able to guarantee rights and obligations. Mertokusumo stated that legal certainty is legal protection against arbitrary actions, which means that a person will be able to obtain something under certain circumstances. According to Kelsen, law is a norm system. Norms are statements that emphasize the "should" or das sollen aspects, including some rules about what should be done. Norms are deliberative human products and actions. Laws contain general rules as guidelines for individuals behaving in society, both in relations with fellow individuals and in relations with the community. The rules become a limit for society in burdening or taking action against individuals. The existence of these rules and the implementation of these rules are the legal certainty. Legal certainty contains two meaningful things. They are the existence of general rules and legal security for individuals. It is with the existence of general rules that individuals can know anything which might be charged or carried out by the State. The doctrine of legal certainty comes from dogmatic juridical teachings which are based on the positivistic school of thought in the world of law. It tends to see law as something autonomous and independent. Due to this thought, law is nothing but a collection of rules. For adherents of scholar, the purpose of law is nothing but guaranteeing the implementation of legal certainty. Legal certainty is realized by law on its nature which only makes a general rule of law. The general nature of law proves that the law does not aim to bring about justice or expediency, but merely for certainty. Inheritance customary law is the legal norms which determine material and immaterial assets from which a person can deliver to his descendants and at the same time regulates the time, method and process of inheritance (Projodikoro, 2010). Inheritance customary law includes rules related to a continuous process from century to century as a continuation and transfer of wealth both material and immaterial from one generation to the next (Sujatmika, 2011) Inheritance customary law has broad meaning in the form of organizing the transfer of wealth from one generation to other next generations. Based on these opinions, it can be concluded that the inheritance customary law regulates the process of transferring tangible and intangible assets. In addition, there are three basic principles in inheritance customary law. These are the principle of harmony, the principle of propriety and the principle of alignment. These three principles can be applied to various problems in the community when they are related to the desa (place), kala (time) and patra (circumstances). By implementing and the process of these three principles in relation to place, time and circumstances, it is expected that all problems can be resolved properly and completely. Referring to inheritance customary law above, it contains several levels namely (a) inheritance customary law is a rule of law, (b) the law contains the process of inheritance, (c) the given inheritance can be tangible and intangible assets (Mourik, 2007).

From the problems described above, research issues are formulated. They are; 1 . What is the legal sanction for the heirs who try to commit the murder of the heir in terms of Balinese customary law?; 2 . How are the legal consequences applied for the heirs trying to commit a murder for the heir in Balinese customary law? The objective of the research is to find out the legal basis for the heirs in Balinese customary law and to find out what the legal consequences for the heirs trying to commit a criminal act against the heir in Balinese customary law.

\section{METHOD}

The method used in this study is an empirical research method focusing on community behavior (law in action), and used primary and secondary data. 
The primary data used in this study are as follows (1) data from Desa Pakraman Sukawati in the form of awig-awig (village traditional rules), (2) interviews with the Prajuru Adat, Bhabinkamtibmas (local authority officers) in charge at Desa Sukawati and (3) interviews with parties related to legal consequences for heirs who try to commit the crime of murder of the testator in terms of customary law of Bali (Case Study in Desa Pakraman Sukawati). As for the secondary data used in this study using primary legal materials, secondary legal materials, primary legal materials including: (1) Constitutional Law of Republic of Indonesia 1945 (2) Law No. 32 Year 2004 concerning Regional Government, (3) Law No. 48 Year 2009 concerning Judicial Power, (4) Government Regulation No. 72 Year 2005 concerning Villages and (5) Regional Regulation of the Bali Province No. 3 Year 2003 concerning Desa Pakraman.

Data is collected directly from the research field. It is done to obtain primary data using observation and interview techniques. Interviews are taken place in Desa Pakraman Sukawati to get indicators about the legal consequences for the heirs who try to murder the inheritor. This is examined using traditional Balinese customary law. This research study uses data processing techniques and qualitative analysis. The collected legal materials are presented in descriptive scientific writing. It is done by describing the specific aspects related to the problem to be discussed and analyzed to get the truth.

\section{III.RESULT AND DISCUSSION}

The customary law system considers that any contrary act is illegal. Customary law recognizes efforts to improve the law when the positive law does not work properly. The definition of customary offense as a one-sided act of a person or group of individuals. Any threatening, offending or disturbing the balance life of the community either material or immaterial against an individual or the community is also part of customary law. These actions will result in a customary reaction (Haar, 2007). The definition of customary offense emphasizes the existence of unilateral actions of individuals or groups both material and immaterial. This can cause disruption of life balance in society. On the contrary, Hilman Hadikusuma sees that "events" can also lead to customary offenses. In his book entitled Hukum Pidana Adat, Hadikusuma stated that the definition of adat (custom) offense is all acts or events that are contrary to propriety, harmony, order, security, a sense of justice and legal awareness of the community concerned. One important thing is noted from the above formulations is disturbed balance in people's lives as an element of offense.

In Balinese society this balance is a harmonious atmosphere described in Tri Hita Karana philosophy, namely: the equilibrium of human relations (pawongan), the equilibrium of the relationship between man and his environment (palemahan), and the balance of the relationship between man and The Supreme Creator (parahyangan). This is the pattern of relationship between human, nature, and God in Balinese community. All of these are aimed at achieving a common goal. This goal is a harmony of human life. Thus, in the concept of Balinese customary law, customary infringement concerns any disruption mentioned balance of three relation above.

Concerning the types of indigenous peoples living under Bali customary law, it is classified into the following categories:

Custom topics related to adulthood, e.g., lokika sangraha (sexual relations between unmarried men and women), drati krama (adultery love affair), gamia gamana (sexual relationship between family members) and salah karma (inappropriate sexual manners, e.g. having sexual intercourse with animals).

Customary offence items related to property, for example, burglary, stealing religious holy properties, destruction of sacred objects, etc.;

Custom practices that violate personal interests, such as mamisuh (slandering), mapisuna (abusing), and more.

Customary offense due to negligence of accomplishing the social responsibilities such as: failure to perform duties as a social member of the village or papeson (obliged social donation in the form of goods)

The local indigenous live in a traditional Balinese community known as Desa Pakraman. Desa Pakraman is a Balinese Hindu community organization which is based on the unity of shared spiritual 
and religious territories. It is the most basic for the patterns of social interaction and relationship. The life balance in Bali consists of three levels, namely:

The level of parhyangan, related to Hindu temples or shrines and social activities of maintaining the temples and shrines).

The level of pawongan, related to the life of Hindu villagers.

The level of palemahan, related to the environmental territories and village social service and karang gunakaya (useful areas) which must be maintained and preserved in accordance with the teachings of Hinduism).

The indigenous Balinese follow the patrilineal kinship system (purusa or kapurusa). According to this system, all family responsibilities and their offspring are basically on the shoulders of the purusa (male). These responsibilities cover the three stages above, namely: (1) parhyangan (maintenance of places of worship, such as family tempe (sanggah), religious activities, family tightened responsibilities related to ancestors like cremation ceremony with its spiritual and religious activities, (2) pawongan (relating to the family life and social service in the local communities (mekrama banjar), and (3) palemahan (preserving the natural environment within the community life and the surroundings). This is again affirming that all activities and responsibilities are falling on man, not a woman. In Balinese community life, women are free from these kinds of responsibilities. A daughter is only taking family responsibility concerning on social services in the community when she is single (unmarried) status. This means that women are taking moral responsibility of the family when they got married. Men have full juridical and moral responsibilities, both before and after marriage. Because the responsibilities are different, a share of inheritance is also different. It is accordance to the burden of responsibilities (parhyangan, pawongan and palemahan). In Balinese expressions, the distribution of inheritance between sons and daughters is governed by the principle of ategen (two parts for boys) and asuwun (one part for girls). This provision does not apply to a child or family member who has recently attended the church, because they no longer belong to the Hindu religion. It is then making it impossible to fulfill their parental obligations.

Although it is possible to give something to all children they got married or left the house for some reasons, inheritance does not interfere with the continuity of family life, especially for sons staying home and continue all family or community obligations stated above. If a daughter receive something from parents without inheritance process, these will be brought to her husband's house when getting married. At her husband's property is called bekel nganten or tetatadan or devotion. This property remains belong to wife and it cannot be calculated with her husband's property, except with the voluntary consent of the wife. Thus, if the marriage is forced to divorced, the property will be transported back to the service. No one can forbid it. As long as the Balinese people live in the Desa Pakraman and still adhere to a patrilineal kinship system. This would be different when someday all the young Balinese are paid bangkung (married by the bride and becomes the member of family). The inheritance process is done by agreement of all parties. On the other hand, this inheritance process may not be based on mutual agreement. There must be some consequences, for instance quarrels in the family about the inheritance process. Other consequence that could be the parents would be shunned by the family or extended family (Windia, 2013).

Desa Pakraman is a Balinese Hindu community organization that is based on the unity of shared area residence and the most basic spiritual and social interaction in the Balinese community. Referring to Article 1 of the Serial Number 11 of the Bali Province Regulation No. 3 Year 2001 specifying that customary law (awig awig) is a rule issued by desa or banjar pekraman. This customary law is functioned as guidelines in the implementation of Tri Hita Karana, in accordance with place (desa), time (kala), and condition (patra) applied in each desa or banjar pekraman, respectively. In 2001, Desa Pakraman had the following tasks:

Make awig awig (customary law).

Arranging village manners.

Arranging the management of village assets.

Together with the government, task of village development in all fields, especially in religion, culture 
and society field.

Fostering and developing Balinese cultural values in order to enrich, preserve, and develop national culture in general and regional culture in particular based on paros, siluluk, selunglung sebanyantaka (deliberation consensus).

According to article 6 of the Bali Province Regulation No. 3 Year 2001 Pakraman have the following authorities:

Resolving customary and religious disputes within the territorial area in according to local customs.

Making decision for village development, especially in the implementation of Tri Hita Karana.

Performing legal acts inside and outside the village in law enforcement

Referring to Article 8 of the Regulation No. 3 Year 2001 about desa Pakraman, it is affirmed that the village peacekeepers have the task of reconciling and resolving customary disputes among other tasks. The same task is also mentioned in the Desa Pakraman Sukawati palet 20 paos 2indik kesukertan, which is "the people of the banjar who spend money. If this is to become a talk or a rebuke, the banjar leaders should think about how to do it. The whole community is concerned, when that is a matter, then the village leaders can solve it).

The elaboration of the district rules and the awig-awig (village traditional rules) constituted a juridical basis in the execution of the duties of village head as a justice of the peace. In accordance with the task of resolving the matter in the background above, it is facilitated by the village head (village steward) who supervises both parties. In accordance with the customary law, Balinese boys are considered to have legal and moral obligations to carry out their responsibilities and obligations (swadharma). It is in the fact of living in the community that the heirs can do bad deeds to the heir (parent) and thus have an effect on the inheritance. This is because heirs do not only have the right to inherit their parents' inheritance, but Bali's customary law also clearly states that the heirs must meet certain conditions such as not committing bad acts to the parents. The heirs must fulfil their religious obligations for the parents. Some bad acts to the parents may include:

Killing parents or attempting to kill parents

Abusing parents

Blasphemy with inappropriate words their parents.

Based on the foregoing, an heir may be denied his right to inherit his parents' inheritance. This is due to Balinese customary law stipulates that heirs will be denied the right to inherit one of the causes if the child is considered ungodly. This means that his position as a child is dismissed by his parents. Regarding the resolution of criminal cases through customary law or court, the first thing to do is refer to Law No. 1 Year 1951 concerning Temporary Actions for Organizing the Composition of Power, Power and Procedures of Civil Courts as the legal basis for resolving criminal acts through adat courts. Referring to Article 5 paragraph (3) sub b of the Drt. Law 1/1951 about civil criminal material law which until now applies to the subjects of the Swapraja (self-government) area and people who were tried before by the Customary Court, still applies to the subjects and that person with the understanding that an act must be considered a criminal offense. But, in the Civil Criminal Code, it is unequal and is considered to be threatened with a sentence of no more than three months in prison or a fine of five hundred rupiahs. It is as a substitute penalty if the customary sentence imposed is not followed by the convicted party. The substitution referred to is deemed commensurate by the Judge with the magnitude of the guilty sentence. If the customary sentence handed down according to the judge, the defendant's mistake may be subject to a substitute sentence as many as 10 years in prison. With the understanding of the judge, it is no longer harmony and the act must be considered as a criminal act. When this is comparable in the Civil Criminal Code, it is considered threatened with a sentence equal to the criminal act.

Regarding Article 5 paragraph (3) sub b of the Drt. Law 1/195, the traditional criminal acts have a comparison with the Criminal Code. Thus, the criminal acts of torture regulated in Article 351 of the Criminal Code cannot be resolved only by adat (customary) judgment. Because the jurisprudence of the Supreme Court only recognizes traditional court decisions or sanctions against criminal acts that have no equal or are not regulated in the Criminal Code. To answer the first problem formulation, it can be 
concluded that the sanctions in Balinese customary courts can be resolved and not yet existed in the Criminal Code or state law. It is determined that the sanctions for violating the heirs' persecution of trying to kill the inheritor occurred in Desa Pakraman Sukawati are the local village peace judge. In this case the Prajuru Adat (village officers) and Bhabinkamtibmas (local authority officers) at Desa Pakraman Sukawati.

According to customary law applied in Bali, the right of the heirs is to inherit the inheritance, while the obligation is a series of activities that the heirs must perform to the parents, their families and their community. It is a religious obligation and a daily duty in society aimed at parents and the good name of the family by performing religious ceremonies and be socialized person in the community. In addition, social obligations related in the Desa Adat (indigenous village) are participating in village social activities such as gotong royong (social service) and other religious ceremonies. The indigenous people generally adopt the patrilineal family system or the term purusa (patrimonial system). It is considered that a man or the sons in the family are the important heirs. The son is the successor and savior of the family line and it is a hope for the parents to depend on later in life. The son must be born from legal marriage. A daughter has the right to enjoy her parents 'inheritance as long as she still lives in her parents' home and is not yet married. However, women can also become heirs when they are given status as purusa called sentana rajeg (groom passionate marriage). They will be the ones responsible for fulfilling the duties assigned to them. The obligation is to pay off the heirs both the material and the immaterial debt. Although the inheritors leave the debts alone without leaving the inheritance, the heirs are obligated to repay the debts left. This would be similar to purusa or kapurusa (the patrilineal) line of patrimony.

According to this kinship system, almost all the responsibilities of family and offspring are basically on the shoulders of the purusa (male). What is meant by responsibility in this case, includes three levels, namely: (1) parhyangan, maintaining places of worship such as temples and religious activities. They are also taking responsibilities on the ancestors ceremonies like funeral, cremation, ngelanus and nyegara gunung (continuation of cremation ceremony; (2) pawongan, having responsibilities in social life and social services as a member of banjar (community); (3) palemahan, maintaining the environment, including family and social environment. All these responsibilities are legally and morally the responsibility of boys as heirs. This can cause a stressful situation and it is found out an attempt to kill the inheritor occurred in Desa Pakraman Sukawati. This might have been worried that she would not get a share inheritance because parents do not involve the child when selling the inheritance. It is a frantic situation. The child pushes his parents into the house and wanted to burn the entire house. The arrival of his eldest brother could prevent the incident. The trial of murder acted out by the heir is a legal event. This criminal legal event was resolved by holding a family gathering attended by the Prajuru Adat (traditional village officers) and Bhabinkamtibmas (local authority officers). The dispute was resolved by consensus in a statement not to repeat the similar act. Otherwise, the heir may lose his right to inherit the goods and properties. This is due to the fact that in both customary law of Bali and the Criminal Code fulfill a law enforcement of losing the rights of inheritance.

The current legislation and under the Constitution of 1945, there are laws and government regulations which can substitute the laws. Understanding the hierarchical and substantial of the law, it is the governing law of the village is the Local Government Law which applies for this research. In the last two Local Government Laws, the Law No. 22 Year 1999 and the Law No. 32 Year 2004, it is stated that village is the unity of the legal community, as defined by Article $18 \mathrm{~B}$ of paragraph (2) of the Constitution of 1945. Earlier, at the time of the Law No. 22 Year 1999, the function of the village justice judge was recognized as one of the village chief 's duties. Referring to Article 101, the duty is to settle disputes in the Village. Even the explanation of the article emphasized the power of binding the resolution at the village-level settlements by stating that: "All disputes settled by the Village Head are binding on the parties at stake". When this law was replaced by the Law No. 32 Year 2004, such provisions were no longer in force. This new law regulates the disputes at the village applied into the Local Regulations. Thus, the only legal ground for a village justice judge is the Emergency Law No. 1 Year 1951 which many have long recognized as the juridical foundation of a village peace judge. Law Year 1951 was actually the Law on Temporary Action to Hold the Union of Power and the Event of the Civil Courts. Indeed, in Article 1 paragraph (1) and paragraph (2) governs the abolition of the general courts formulated by the Dutch Government of the West Indies from the lowest to the highest and the 
gradual abolition of the Swapraja (self-government) and Indigenous Courts. This law does not diminish the power of the village justice judge, as stipulated in Article 1 paragraph (3) of the law. Further, Article 1 paragraph (3) states that: "The provisions of paragraph (1) do not in any way diminish the right of power which has so far been granted to the justices of the peace in villages. It referred to Article 3a Rechterlijke Organisatie". Here, the Emergency Law refers to the rules of the Dutch East Indies, Article 3a Rechterlijke Organisatie (RO). In Dutch colonial times, the village peace judge formally recognized the law since 1935. It was actually before that the village judge is already in Indonesian society. With regard to the rights of the village justice, Article 3 further states the following:

Matters for examination by customary law as the authority of the judiciary of the minority community (village magistrate) are still subject to their examination.

What is specified in paragraph (1), shall not in any way diminish the authority of the parties to each time submit its case to the judge referred to in clause 1.2.

The judges referred to in paragraph (1), adjudicate on customary law, they cannot impose penalties.

The term "authority for village peace judge" referred to in Article 1 paragraph (3) of the Emergency Law Number 1 Year 1951 can functioned as the village peace judge. Based on the law, the function of the village peace judge is to examine and try cases that are under his authority according to customary law. Even though Emergency Law No. 1 Year 1951 does not clearly get rid of the existence of a village peace judge, there are doubt the existence of a village peace judge when it relates to Law No. 48 Year 2009 concerning Judicial Power. Article 13 paragraph (1) of the law stipulates that all courts in all regions of Indonesia are state courts and are determined by law. General Explanation No. 7 of this law states that: "affirmation that the judiciary is a state court, intended to cover all possibilities for or the holding of a self-defense court or customary court conducted by a non-state judicial body". Because the village court (village peace judge) is not a state court, according to this view after the enactment of the Basic Law on Judicial Power, this court is no longer exist (Berata, 2007), this law is considered a bell death for the village peace judge (Hazairin, 2009).

Apparently, this view is based on a wrong understanding of the village peace judge which is understood as part of the adat (customary) court. This misconception was shown by Atmaja in his writings published in Pro Justisia Magazine entitled "Hakim Perdamaian Desa dan Undang-undang Pemerintahan Desa" (Village Peace Judge and the Law on Village Governance). According to Atmaja, there is no doubt about the existence of a village peace judge. His view was based on several arguments. First, the village court (village peace judge) is not the same as the Customary Court as intended by Emergency Law No. 1 Year 1951. In this emergency law which is explicitly abolished are the governor's court, self-employment court, and customary court, while the power village peace judges are still recognized. Second, the village peace judge is not really about giving authority to judge (Atrubutie van Rechtmacht) where the parties to the litigation are not obliged to submit their cases to the village peace judge, but on a voluntary basis. Citing Soepomo, he said that district court judges were indeed obliged to pay attention to as many village decisions as possible if they were deemed to be in accordance with their obligations to adjudicate themselves according to customary law. District court judges were not bound by village peace judge decisions. In addition, according to Atmadja, the words "judge" in the term village peace judge is not "judge" in the true sense of the word as a judge at the district court. This final opinion is based on Article 3a paragraph (2) which does not reduce the right of the parties concerned to advance before an ordinary judge. In the case of punishment, the village peace judge cannot impose a sentence as determined in the Criminal Code, but it can only determine the village customary reaction (adat reaaktie) to restore balance or harmony in the life of the community (Atmadja, 2010).

Referring to this argument given by Atmadja above, there is no doubt about the existence of a village peace judge in national legislation. The existence of a village peace judge is still recognized based on Article 1 paragraph (3) of the Emergency Law Year 1951 and is not subject to the provisions of Article 13 of Law No. 48 Year 2009 concerning judicial power. At the level of Government Regulation, the function of the village peace judge is mentioned in Government regulations No. 72 Year 2005. This regulation is concerned on villages. This current government regulation must be applied as the basis for drafting Regional Regulations governing the duties and obligations of the Village Head as mandated by Law No. 32 Year 2004 (Article 208). In this Government Regulation, recognition of the 
functions of village peace judges is summarized in Article 15 as an obligation of the Village Head. More clearly, the Article states that "In carrying out the duties and authorities of the Village head has the obligation to reconcile community disputes in the village". Thus, the function of the village peace judge is recognized at the level of Government Regulation.

The existence of a village peace judge is also recognized in the Regional Regulation of the Province of Bali. It is regional regulation of the Province of Bali No. 3 Year 2001 concerning Desa Pakraman as amended by Regional Regulation of the Province of Bali No. 3 Year 2003. Although explicitly the term "village peace judge" is not mentioned in The Regional Regulation, but the function of the village peace judge is to resolve and reconcile disputes that occur in the village community is known and recognized in the Regional Regulation. The function is recognized as the task of the Prajuru (village officers) Desa Pakraman. For more details, Article 8 Regional Regulation No. 3/2001 expressly states that Desa Pakraman preachers have the task of working for peace and resolution for community disputes. The existence of Desa Pakraman preachers' task of pursuing peace and resolving disputes cannot be interpreted as an acknowledgment of the function of the village peace judge. This recognition is important because with this the Desa Pakraman preacher has a strong foundation to resolve customary cases occured within the territory of the Desa Pakraman. The existence of village peace judge was also found in the District Regulations. In the Regency of Gianyar, this can be found in the Regional Regulation of the Gianyar No. 10 Year 2002 concerning the Organization Structure of the Village Government. In contrast to Bali Province Regulation No. 3/2003 which places the responsibility of implementing the function of the village peace judge in Desa Pakraman preachers. The Regional Regulation of the Gianyar Regency assigns the Perbekel (Chief of nationally authorized village) to take this responsibility. Article 5 of the Regional Regulation of the Gianyar Regency states that the Perbekel has the function of reconciling disputes in the village.

\section{IV.CONCLUSION}

This can be concluded that legal sanctions for heirs who trying to murder can be resolved at the village. This is in line with the customary law. It is not yet exist and regulated in the criminal code or state law. Sanctions for violating the heir persecution occurred in Desa Pakraman Sukawati were determined by village peace judge called Prajuru Adat. The legal consequences for the heirs try to commit the murder is regulated in Balinese customary law. It is based on Article 838 of the Civil Code which states that those who have been convicted of killing or attempting to kill the inheritor, the consequence is zero inheritance. It is a principle that every person including a person who has inheritance rights does not receive anything. This has been determined by law and it is excluded from inheritance. It is one of those who has been convicted or blamed for killing or attempt to kill the inheritor.

Based on the description of the conclusions above, the author recommend some suggestions. These suggestions are; it is recommended that the government especially the General Assembly of Desa Pakraman decide on inheritance rights of daughters (biological or adopted daughters) to inherit half of the male line inheritance after being deducted $1 / 3$ of it and the preservation interests considering juridical aspects and prioritizing togetherness to maintain and develop harmony among the heirs. It is also recommended to village peace judges to better review the legal basis in deciding customary cases. This is because the Balinese legal culture tends to submit customary violations to the customary village apparatus. The absence of a judicial basis that gives the authority of the customary peace judge to adjudicate adat (customary) disputes can have an impact on the confusion of authority which has the right to adjudicate customary disputes of applicable regulations.

\section{REFERENCE}

Atmadja, D. G. (2010). Hakim Perdamaian Desa dan Undang-undang Pemerintahan Desa. Pro Justitia.

Berata, I. D. M. (2007). Lembaga Hakim Perdamaian Desa Ditinjau Dari Segi Hukum Positif. Majalah Pengayoman Nomor 9.

Haar, B. T. (2007). Asas- asas dan susunan Hukum adat. Jakarta: Pradnya Paramita.

Hazairin. (2009). Hakim Desa. Jakarta: Bhratara.

Mourik, M. J. . Van. (2007). Studi Kasus Hukum Waris. Bandung: Eresco. 
Muhammad, Bushar. (2009). Pokok-Pokok Hukum Adat. Jakarta: Pradnya Paramita

Nantri, A. P. (2007). Kedudukan Ahli Waris Yang Beralih Agama Menurut Hukum Adat Waris di Kabupaten Badung. Denpasar: Universitas Udayana.

Projodikoro, W. (2010). Hukum Warisan di Indonesia. Bandung: Sumur.

Sujatmika, K. (2011). Tindak Tutur dalam Dialog Film Garuda di Dadaku Karya Salman Aristo (Sebuah Tinjauan Pragmatik). Universitas Muhammadyah Surakarta. Retrieved from http://eprints.ums.ac.id/11567/

Windia, W. P. (2013). Hukum Adat Bali. Denpasar: Udayana University Press.

Undang-Undang Nomor 32 Tahun 2004 tentang Pemerintahan Daerah.

Undang-Undang Nomor 48 Tahun 2009 tentang Kekuasaan Kehakiman.

Peraturan Daerah Propinsi Bali Nomor 3 Tahun 2003 tentang Desa Pakraman.

Peraturan Pemerintah Nomor 72 Tahun 2005 tentang Desa. 